\title{
Work Behavior Analysis of FMCG Salesman
}

\author{
Minchao Liao, Lili Fan \\ School of Economics and Management, Southwest Jiaotong University, Chengdu, China \\ Email: joy7756@sina.com, fanlili1106@126.com
}

Received 17 May 2014; revised 19 June 2014; accepted 8 July 2014

Copyright (C) 2014 by authors and Scientific Research Publishing Inc.

This work is licensed under the Creative Commons Attribution International License (CC BY).

http://creativecommons.org/licenses/by/4.0/

(c) (i) Open Access

\begin{abstract}
In the background of cut-throat competition in the FMCG industry, work behaviors of the salesman at the forefront of the business play an important role to achieve the marketing objectives. Based on the sales behaviors and related scale development theory, and following the logic of analyzing FMCG sales order work stages first, and then the sales order work contents of each stage, and the work behavior characteristics of sales order of each stage at last, the work behavior of FMCG salesman is discussed in this paper.
\end{abstract}

\section{Keywords}

Sales Order, Work Behavior, Fast-Moving Consumer Goods, Rating Scale, Measurement-Item

\section{Raise the Problem}

China FMCG market has developed rapidly in recent years, and the competition has become increasingly fierce. In order to compete for the market, the fast consumer goods manufacturers are all dispatching a large number of salesmen to the market of dealers and terminal channels, to develop, maintain and expand the order. The personal sales order ("take" orders) way of work behaviors of the salesmen at the forefront of the market doubtless plays an important role in achieving the manufacturers marketing goals.

\section{Literature Review}

The related literature at home and abroad in this study can be divided into three aspects: behavior research, salesman's work responsibilities and behavior scale development research. On the behavior research, Kohn and Sehooler (1978) collected a large number data of interaction of human characteristics and situational characteristics, and found that the people's impact on the job is more dramatic than work's impact on the people [1]; Chatman (1989) think people have diffuse and lasting effect on the scene, which must be studied continually [2]; Diener, Larsen, Emmons (1984) pointed out that, when the environment meet the people's needs and their intentions are satisfied, they will be very happy [3]. Therefore, when the people and the environment situation is con- 
sistent, their performance will be higher, otherwise it will be lower; Cascio (1998) study from the performance perspective of human resources management, he thought, the so called critical incident refers to the difference caused by the effective and ineffective work behavior [4].

Qu Yunbo (2007) thinks: salesman need to do sales presentations, handle objections, help with sales display and end transaction [5]. Kerin (2006) mentioned in his works: the salesman need to find customers, contact customer, demonstrate the goods, make the deal and follow the transaction [6]. In practical work, the various FMCG enterprises have also developed specific job requirements for their own sales staff, such as the eight steps of Uniform Group, and eight visit steps of China Grain and Oil Group.

From the above literature, the existing research about salesman's responsibilities and behavioral characteristics research mainly focus on general description, there is few that focus on specific fast-moving consumer goods industry. And there are still no relevant research results about how to analyze consumer behavior of salesman. This paper attempts to start with the most basic elements to do the research of work behavior of salesman.

\section{FMCG Salesman's Job Analysis}

FMCG is short for Fast Moving Consumer Goods, the sales order is the activity that salesman use promotion to the terminal retailer and business negotiations to make the order. Xie Zongyun (2009) and many other scholars divide sales order work into three parts: terminal call, terminal development, and terminal maintenance. On this basis, with the investigation to the FMCG enterprises' sales representatives, this paper made a further subdivision for the above three major categories of work.

\section{Terminal Call Work Breakdown}

Terminal call is an important link of sales representative to obtain orders, because of its importance, most FMCG manufacturers made detailed requirements for the terminal call process, such as Coca Cola's terminal visit eight steps: preparation $\rightarrow$ examination of outdoor advertising $\rightarrow$ say hello to customers $\rightarrow$ do vivid point of sale $\rightarrow$ check inventory of point of sale $\rightarrow$ advise order and confirmation order $\rightarrow$ thank customers. Procter \& Gamble terminal call operation standards: 1) plan, make access to the target; 2) observe customers' business places, see the product display shelves, distribute and help sales and volume; 3) sales presentation; 4) collection; 5) help sales: post the advertising; training customer personnel about product knowledge; 6) record visit results and opportunities; 7) analysis, review the access process, and summed up gains and losses. Unilever $6 \times 9$ basic visit process. "6" is the six tools: customer data card (call sheets), sales reports, sales folder, sales presentation material/tools, commodity display material/tools, daily sales priority task report. " 9 " is the 9 steps: refer to plans $\rightarrow$ start visiting $\rightarrow$ store check $\rightarrow$ collection $\rightarrow$ s ales presentation $\rightarrow$ end sales $\rightarrow$ record and report $\rightarrow$ display work $\rightarrow$ end and evaluation. Johnson's visit eight steps: planning and preparation $\rightarrow$ inspect stores $\rightarrow$ collection $\rightarrow$ sales presentations $\rightarrow$ goods display $\rightarrow$ establish a good customer emotional relationship $\rightarrow$ complete the report $\rightarrow$ analyze results. Kangshifu's visit eight steps: plan and prepare $\rightarrow$ send greetings $\rightarrow$ product display $\rightarrow$ check inventory $\rightarrow$ advise the sales $\rightarrow$ advertise the use $\rightarrow$ do administrative work $\rightarrow$ thank and evaluate.

From the above company visit work, the general process of FMCG enterprise terminal visit can be summed up, as shown in Table 1.

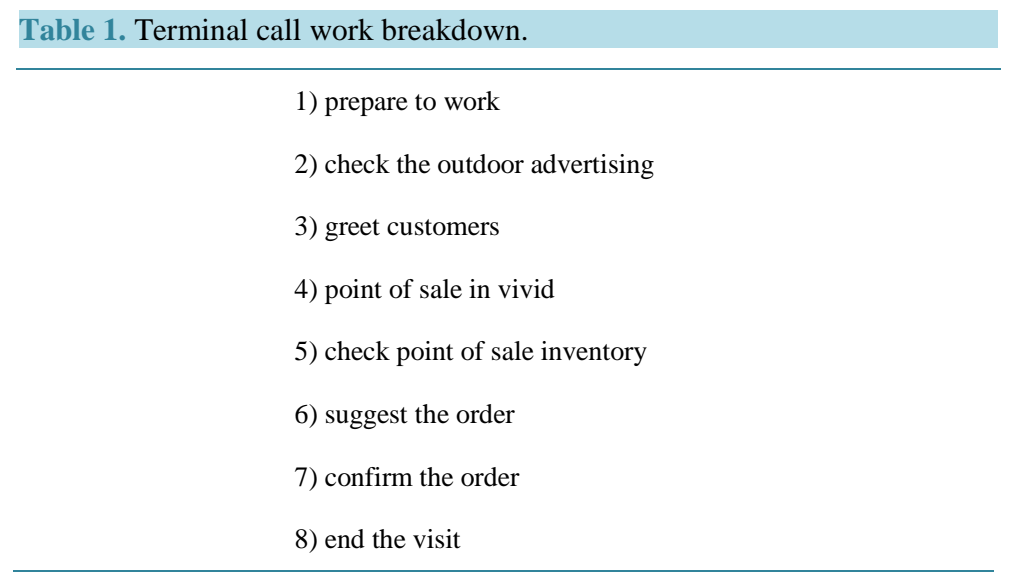


Table 2. Terminal development work breakdown.
1) prepare to work
2) learn about the terminal
3) business conversation
4) reach an agreement

\section{Terminal Development Work Breakdown}

To improve the product sales, salesman will continue to develop new terminals in the every visit. According to the investigation results of part of FMCG manufacturers like the Farmer Mountain Spring, Fung Valley Wine and Nan Fang Lue consulting company, the terminal development work segmentation is done.

The Farmer Mountain Spring's develop new customers steps: 1) establish confidence, make enough preparation, learn product knowledge and professional skills; 2) understand the new customers, including point of sale type, scope of business, the main customer groups, the boss himself; 3) make the visit strategy; 4) visit; 5) follow-up work, including complete new customer data card and communicate delivery matters with distributors, report to the relevant business executives, and record new customers into the visit route etc.

Nan Fang Lue consulting company summarizes the development of terminal work flow by investigating part of FMCG enterprises: terminal research $\rightarrow$ plan $\rightarrow$ visit invitation $\rightarrow$ chose a topic $\rightarrow$ display promotion $\rightarrow$ handle objections $\rightarrow$ negotiate cooperation $\rightarrow$ make agreement $\rightarrow$ customer service.

Fung Valley Wine's terminal development is mainly divided into four stages: 1) preparation stage, including prepare companies' relevant information, competitor's information, the terminal data, the predetermined plan; 2) negotiation. Determine negotiating goals, evaluate negotiation opponent; 3) talk stage. The main point is keep the conservation to the terminal operators in a good negotiation climate; 4) reach an agreement. Make the contract timely, creating a win-win situation.

After the summary, it is easy to find that terminal development is actually the first visit of the salesman, Table 2 shows the terminal development work breakdown.

\section{Terminal Maintenance Work}

Xie Zongyun (2009) think that to maintain the customers, the salesman need to carry out a series of management work in order to maintain good customer relationship and keep the customer long-term cooperation, not to the loss customers. Qincen (2010) also believe that maintain the customer terminal is not a short duration of time thing, it needs long-term unremitting efforts. This phase of the work is more important in maintaining customer relationship, which means beyond the company's sales policy, the salesman should fully mobilize all resources to strive for and use charm to give the terminal operators the emotional care and satisfaction, and create a good social environment for sales.

\section{Limitation and Prospection}

This paper attempts to analyze work behavior of salesman in FMCG industry, the research is mainly based on the most basic elements, using them as the breakthrough point, hoping to play a valuable role in this aspect.

Above analysis is just initial analysis for sales order work behavior, whether such behavior characteristics are credible and effective or not, it needs further discussion about the behaviors items, and the reliability and validity analysis and test should be done. About this research, firstly it needs to design the above actions into measure items, pretesting them through small-scale survey, in order to test the measurement items of content validity. In this process, it may remove or merge some items that do not meet the requirements of concept consistency. After this, choose the suitable FMCG salesman samples to do investigation, analyze the correlation and factor on items, to streamline and optimize measurement items. Because of the limited length, the work will be performed in the following research.

\section{References}

[1] Kohn, M.L. and Schooler, C. (1978) The Reciprocal Effects of the Substantive Complexity of Work and Intellectual 
Flexibility. American Journal of Sociology, 84, 24-52. http://dx.doi.org/10.1086/226739

[2] Chatman, J. (1989) Improving Interactional Organizational Research: A Model of Person-Organization Fit. Academy of Management Review, 14, 333-349.

[3] Diener, E.L. and Emmons, R. (1984) Person X Situation Interaction: Choice of Situations and Congruence Response Models. Journal of Personality and Social Psychology, 47, 580-592.

[4] Cascio, W.F. (1998) Applied Psychology in Human Resource Management. 5th Edition, Prentice-Hall, Upper Saddle River, 58-79.

[5] Qu, Y.B. (2010) Marketing Coach. Business Management Press, Beijing.

[6] Kerin, R.A., Hartley, S.W., Berkowitz, E.N. and Rudelius, W. (2008) Marketing. Posts and Telecom Press, Beijing, 527-548. 
Scientific Research Publishing (SCIRP) is one of the largest Open Access journal publishers. It is currently publishing more than 200 open access, online, peer-reviewed journals covering a wide range of academic disciplines. SCIRP serves the worldwide academic communities and contributes to the progress and application of science with its publication.

Other selected journals from SCIRP are listed as below. Submit your manuscript to us via either submit@scirp.org or Online Submission Portal.
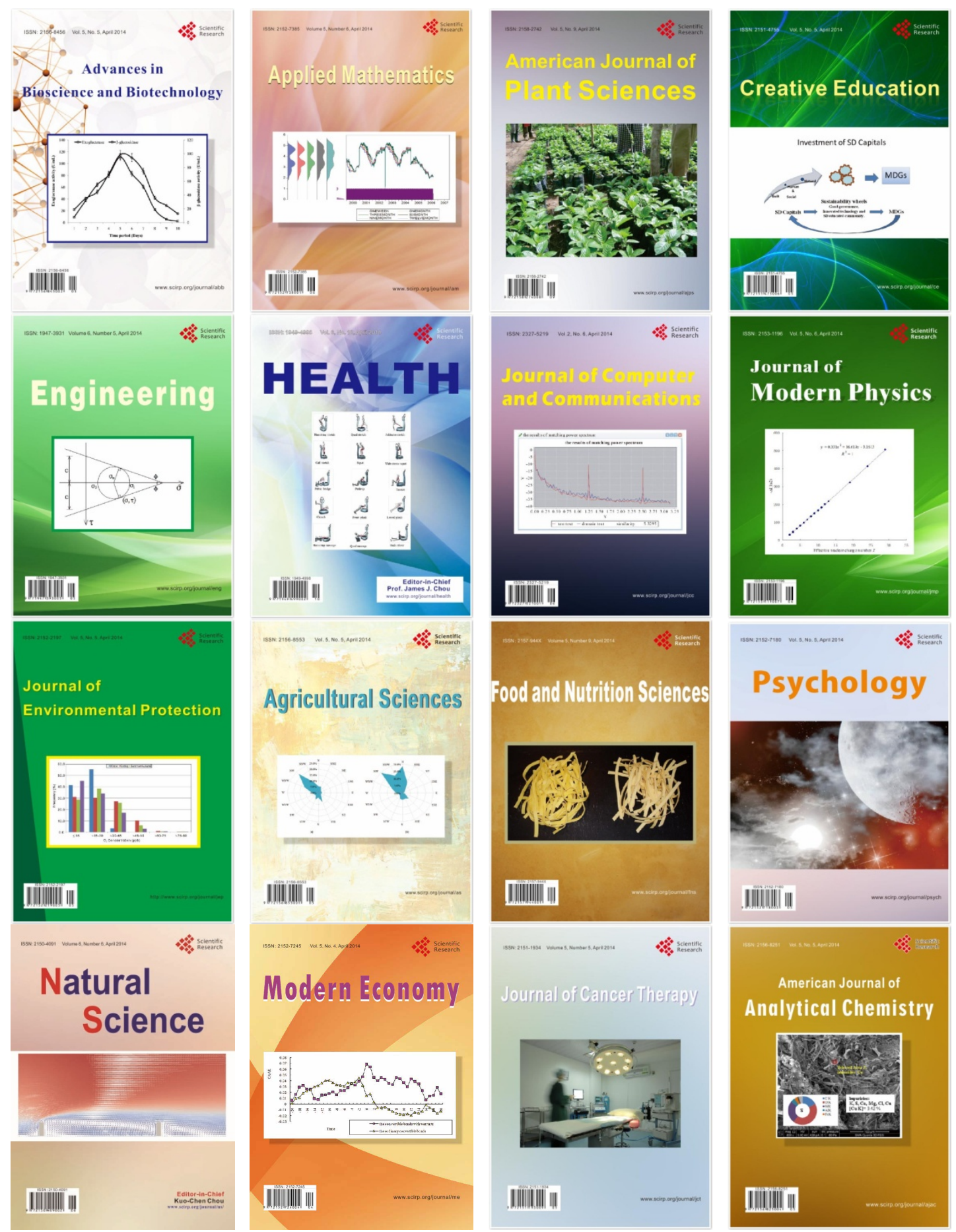